\title{
The Effects and Challenges of Computer Based Learning on Academic Performance of Distance Leaning Students of University of Maiduguri, Borno State, Nigeria
}

\author{
Aminchi Daniel, Kefas Sallau Buba \& Bello Imam Ali
}

\begin{abstract}
The study determine: the Effects and challenges of Computer based learning on academic performance of distance learning students of university of Maiduguri, Borno state, Nigeria. The study examine the effects of computer based learning on the poor academic performance of distance leaning students of University of Maiduguri. Challenges of computer based learning on poor academic performance of distance learning students of University of Maiduguri. Two research questions were raise to guide the study: What is the effects of computer based on distance learning student academic performance University of Maiduguri. What are the challenges of computer based on academic performance of distance learning student, University of Maiduguri The study is delimited to one hundred and twenty (120) distance learning students from faculty of education, department of physical and health education, department of continuing education and extension services, department of science education and department of library and information science, which were used to drawn 30 students from each department which made up of a total one hundred and twenty sample size (120) of three hundred level students were used (300 level). The data collected presented in tables and analysed using frequency and percentages. The finding shows that, there is a great effects of computer based learning on distance learning students of university of Maiduguri. The results also revealed that there is challenges of commuter based learning as the students does not more time for the computer based learning and limited access to computers. Among the recommendation of this study was; the University of Maiduguri should look at how each students should have his/her laptop for effective computer based learning for distance learning students. University of Maiduguri management should make sure that all resources and man power of the ICT are in good ordr before go into computer based learning.
\end{abstract}

Keywords: Effects, Challenges, computer based, Learning, Distance Learning

DOI: $10.7176 / \mathrm{JEP} / 12-15-07$

Publication date:May $31^{\text {st }} 2021$

\section{Introduction}

Computer-based learning is becoming more and more widespread and it has been important especially at difficult subjects in science for over two decades. Nowadays by using computers researchers studying on molecular chemistry, medical chemistry, accounting molecular orbital are managed to ease collecting and processing data and gain speed (Zielinski \& Swift, 1997).

Successful professional educators are not confronted replacing traditional applications with new ones.Gilbert (1996) indicated that instructors must avoid being impatient for integrating information technology in learning and teaching. It is not possible to wait that the replacement of the traditional education completely with an information technology assisted method of instruction in a single semester. Therefore, it can be used the combination of computer technology with traditional method and constituting gradual process instead of a quick change.Computer is a device, which presents wonderful opportunities for learning and teaching processes. Using to teach, manage, show and communicate made the computer unique compared the other learning devices.

Integrating technology into teaching and learning is not a new challenge for universities. Since the 1900s, administrators and faculty have grappled with how to effectively use technical innovations such as video and audio recordings, email, and teleconferencing to augment or replace traditional instructional delivery methods (Kaware \& Sain, 2015; Westera, 2015).

Information communication technology refers to the totality of methods and tools that are used in gathering storing, processing and communicating information. It has found application in virtually all the available profession in the world. Professionals in different fields called it by different names. ICT encompasses all the technologies used to transmit or disseminate information to an audience. These cover internet services provision. Telecommunication equipment and services, media and broadcasting and other related information and communication activities, modern ICT products include e-mail, voice mail, FAX, internet, electronic bulletin boards, cellular phones, and videoconferencing among others.

The information age has made the world a global villages such that information an easily be share, no matter where one is. The effects of this is that people are being influenced in almost every aspect. The impact of computer base learning is currently in relation to use of digital media, primarily computers and internet to facilitate teaching and learning. ICTs are the technologies used in conveying, manipulation and storage of data 
by electronic means, they provide an array of powerful tools that may help in transforming the present isolated teacher-centered and text-bound classrooms into rich, student focused, interactive knowledge environment. Abdul-Rahman, Z. (1994).

In the teaching profession, distance education programme is now accepted world-wide as a standard alternative mode of education due to the use of computer base (Ojoketa \& Adepouju, 2007) computer improves instruction and more learners can be catered fir. For example Distance Education University in China has an enrolment of 1,000, 000 students (Ogunsheye, 2000). In health and broadcasting sectors computer has be used to provide information with the aim of bringing about social transformation.

Learners refers to the perception, prerequisite knowledge, style, skills and understanding as various characteristics as it affect web-based learning. The learning style of individual learners affect their learning process because they have different preferences that assist them in the learning processing the difference is one of the reason why some learners find it easy to learn in a particular learning environment, whereas others find it difficult in the same one (Dung \& Florea, 2012). Based on gender, culture and social differences, learners do react differently to learning style and this in turn, have effect on how they adapt to computer based learning.

\section{Statement of the Problem}

Education researcher have maintained an interest in the effective prediction of students' academic achievement at Universities level, therefore, federal and state Government are responsible for the provision of computer for both the teachers and students. And in many of the developing countries, power supply is poor and facilities for interest connectivity are yet to be installed properly. Computer based study depends on efficient of communication system and consistent electricity in which these are lacking in our Nigerian Universities. In Nigeria, there is a large segment of the population that is computer illiterate, even among the educated elite very few are computer compliant, and this is especially true in the rural areas. One of these challenges is inability of teachers to assist the students develop the ability and knowledge necessary to make them use the computer effectively,

\section{Objectives of the Study}

This paper examine the problem associated with students poor academic performance among Distance learning students in learning centre in the University of Maiduguri, Borno State, Nigeria.

The objectives of the study are to evaluate;

(i). effects of computer based learning on the poor academic performance of distance leaning students of University of Maiduguri

(ii). Challenges of computer based learning on poor academic performance of distance learning students of University of Maiduguri

\section{Research Questions}

(i). What is the effects of computer based on distance learning student academic performance University of Maiduguri?

(ii). What are the challenges of computer based on academic performance of distance learning student, University of Maiduguri

\section{Review}

\section{Effects of Computer Based learning on poor Academic Performance}

Thus, many researchers have emphasized on the need to include non-cognitive factors such as personality, motivation, learning strategies and beliefs in investigation of individual's differences in academic achievement. In other words, contemporary researchers are interested in whether or not other individual differences than cognitive ones for example intelligence, cognitive ability may be used to predict academic achievement. The present study aims at how computer based determining or predict academic achievement of students Blum, K.D., (1999).

Computer has used to be produced for teaching, manage, show and communicate, but other devices, whichare used to learn, are less effective than computer. Computer -based learning (CBL) is a method, which use computer in learning media, strengthening students' motivation and education process. It gives opportunities to both students and teachers to learn by their speed and combine active learning with computer technology. Collette \& Collette (1989) explained that using computer increase motivation and desire to lectures and laboratory in the process of learning. There are a lot of important reasons for using computer and World Wide Web in chemistry education. Educator not only can gather many materials from various centers. But also they can get text, graph, audio, video, picture, animation and simulation in the same media to students. Many studies also supported the idea that computer-based learning has positive effect on students' achievements and attitudes (Aiello \& Wolfe, 1980; Burns \& Bozeman, 1981; Chang, 2002; Russell et all, 1997; Sanger \& Greenbowe, 
2000). The aim of this study is to understand the importance of CBL in analytical chemistry education and its effect on

students`attitudes and achievements.

Integrating technology into teaching and learning is not a new challenge for universities. Since the 1900s, administrators and faculty have grappled with how to effectively use technical innovations such as video and audio recordings, email, and teleconferencing to augment or replace traditional instructional delivery methods (Kaware \& Sain, 2015; Westera, 2015). Within the past two decades, however, this challenge has been much more difficult due to the sheer volume of new technologies on the market. For example, in the span of 7 years (from 2008 to 2015), the number of active apps in Apple's App Store increased from 5000 to 1.75 million. Over the next 4 years, the number of apps is projected to rise by $73 \%$, totaling over 5 million (Nelson, 2016). Further compounding this challenge is the limited shelf life of new devices and software combined with significant internal organizational barriers that hinder universities from efficiently and effectively integrating new technologies (Amirault, 2012; Kinchin, 2012; Linder-VanBerschot \& Summers 2015; Westera, 2015).

Many organizational barriers to technology integration arise from competing tensions between institutional policy and practice and faculty beliefs and abilities. For example, university administrators may view technology as a tool to attract and retain students, whereas faculty may struggle to determine how technology coincides with existing pedagogy (Lawrence \& Lentle-Keenan, 2013; Lin, Singer, \& Ha, 2010). In addition, some faculty may be hesitant to use technology due to lack of technical knowledge and/or skepticism about the efficacy of technology to improve student learning outcomesUniversities that fail to effectively integrate technology into the learning experience miss opportunities to improve student outcomes and meet the expectations of a student body that has grown accustomed to the integration of technology into every facet of life.

\section{Challenges of Computer Based Learning in Nigerian Universities}

Computer based learning or E-learning technology development is faced with a lot of challenges in Nigerian Universities. One of these challenges is inability of teachers to assist the students develop the ability and knowledge necessary to make them use computer based studies effectively. In many computer based learning projects, students face some challenges of bad perception during their studies; lack of pedagogy in their curriculum, lack of user touch and feel in their computer based learning platform (Allen \& Seaman 2003, Ostund 2005).

There have been some efforts by developing counties to adopt the use of computer based learning. However according to Okwilage Njoku (2002), computer based learning has not developed considerably to an appreciable extent in African due to many inhibitive factors. The biggest problem is that of illiteracy , infrastructure is another major problem that needs to be addressed in the developing countries that computer based can easily be used. In many of the developing countries, power supply is poor and facilities for internet connectivity are yet to be installed. Computer based leaning depend on efficient communication system and these are lacking. For example in African, south African has more than $90 \%$ of the connectivity of the entire continent (Jenson cited in Karelse \& SeyeSylla, 2000).

Also some e-learning studies conducted in developing countries show lack of vision and framework in implementing e-learning lead to failure of these projects (Pal, 2006, Kizito \& Bijan, 2006). Lack of both technical and social skills required for the implementation of computer based learning in developing countries are; limited or lack of connectivity in many developing countries including Nigerian Universities impedes access to online learning. Computer based learning requires equipment that can facilities learning, but in some of Nigeria Universities, the equipment such as computer, digital technology, and internet are and available for proper utilization. Also software enable educators to design and develop learning content. These software are costly and not available for use in some of our universities, to facilitate computer based learning. No combination of connectivity, equipment and software will achieve anything if people are not trained to use them (Daniel, 2009). Some lecturers and students are not trained to make use of some of the e-learning equipment.

Computer-based learning is becoming more and more widespread and it has been important especially at difficult subjects in science for over two decades. Nowadays by using computers researchers studying on molecular chemistry, medical chemistry, accounting molecular orbital are managed to ease collecting and processing data and gain speed (Zielinski \& Swift, 1997).

Successful professional educators are not confronted replacing traditional applications with new ones.Gilbert (1996) indicated that instructors must avoid being impatient for integrating information technology in learning and teaching. It is not possible to wait that the replacement of the traditional education completely with an information technology assisted method of instruction in a single semester. Therefore, it can be used the combination of computer technology with traditional method and constituting gradual process instead of a quick change.Computer is a device, which presents wonderful opportunities for learning and teaching processes. Using to teach, manage, show and communicate made the computer unique compared the other learning devices.

In summary, some of the challenges of computer based learning in Nigerian Universities are; inadequate 
security for Universities Cyber Café; inadequate computer based experts or manpower to train both the staff and the students; internet facilities adopted in most Universities cannot afford it; inadequate supply of electricity to computer based learning centres for effective teaching and learning; inadequate funding of the universities to buy e-learning technology and inadequate laptops or computers for both the students and staffs.

\section{Methodology}

\section{Research Design}

The study adopted a survey design to determine the challenges and effects of computer based learning on poor academic performance of distance learning students of University of Maiduguri, faculty of education. The target population for the study comprises of one hundred and twenty (120) distance learning students of university of Maiduguri, faculty of education. The sample size were drawn from department of physical and health education, department of continuing education and extension services, department of science education, and library and information science, which were used to drawn 30 students from each department which made up of a total of one hundred and twenty sample size (120) of three hundred level students were used (300 level).

A self-developed questionnaire was used to collect the relevant data for the study. The questionnaire has ten items. The three point Likerts scale of agreed, disagreed and undecided were used. The data collected was analyzed using descriptive statistic of frequency count and percentage.

Results

Table 1. Effects of Computer Based Learning on students poor Academic Performance

\begin{tabular}{|l|l|l|l|l|}
\hline Statement & Agreed & Disagreed & Undecided & Total \\
\hline Computer based learning make me lazy & $\begin{array}{l}63 \\
(52.5 \%)\end{array}$ & $\begin{array}{l}41 \\
(34.2 \%)\end{array}$ & $\begin{array}{l}16 \\
(13.2 \%)\end{array}$ & 120 \\
\hline Computer based learning discourage me from reading hard & $\begin{array}{l}43 \\
(35.8 \%)\end{array}$ & $\begin{array}{l}56 \\
(46.6 \%)\end{array}$ & $\begin{array}{l}21 \\
(17.5 \%)\end{array}$ & 120 \\
\hline $\begin{array}{l}\text { Computer based learning help me to improve on my academic } \\
\text { performance }\end{array}$ & $\begin{array}{l}27 \\
(22.5 \%)\end{array}$ & $\begin{array}{l}75 \\
(63.3 \%)\end{array}$ & $\begin{array}{l}17 \\
(14.2 \%)\end{array}$ & $\begin{array}{l}520 \\
(45.8 \%)\end{array}$ \\
\hline Computer based exam is all about guessing work & $(50.7 \%)$ & $04(3.3 \%)$ & 120 \\
\hline I preferred computer based exam more the pen and paper exam & $\begin{array}{l}20 \\
(16.7 \%)\end{array}$ & $\begin{array}{l}89 \\
(81.7 \%)\end{array}$ & $11(9.2 \%)$ & 120 \\
\hline
\end{tabular}

Source: field survey 2019

The first objectives of the study was to assess the effects of computer based learning on poor academic performance. The respondents were asked to rate their opinion on a likert scale on the major effects of computer based learning on academic performance. On the opinion on how Computer based affects the performance of students the results reveals on item I how based learning make students lazy, $(52.5 \%)$ of the respondents agree while $(34.3 \%)$ disagreed, and about $(13.3 \%)$ of the respondents were undecided. Also on item II: on how Computer based learning discourage me from reading hard $(35.8 \%)$ of the respondents agreed, $(46.6 \%)$ were disagreed, and (17.5\%) of the respondents were undecided. On item III: whether computer based exam help students to improve on their performance, about $(22.5 \%)$ of the respondents agreed, and $(63.3 \%)$ of the respondents disagreed, while $(14.2 \%)$ were undecided. Item IV: above shows $(45.8 \%)$ of the respondents were agreed and $(50.8 \%)$ were disagreed while $(3.3 \%)$ of the respondents were undecided on Computer based exam is all about guessing work.

Lastly on item V: preferred computer based exam than pen and paper exams of students performance $(81.7 \%)$ of the respondents agreed and $(16.7 \%)$ were disagreed while $(9.2 \%)$ were undecided. The results shows that computer based learning has a great effects on student academic performance. 
Table 2: Challenges of Computer Based learning in University of Maiduguri

\begin{tabular}{|l|l|l|l|l|}
\hline Statement & Agreed & Disagreed & Undecided & Total \\
\hline $\begin{array}{l}\text { Poor management is one of the challenges of computer based } \\
\text { learning in University of Maiduguri }\end{array}$ & $\begin{array}{l}63 \\
(52.5 \%)\end{array}$ & $\begin{array}{l}41 \\
(34.2 \%)\end{array}$ & $\begin{array}{l}16 \\
(13.3 \%)\end{array}$ & 120 \\
\hline $\begin{array}{l}\text { Inadequate feedback is also a challenges of computer based } \\
\text { learning in Unimaid }\end{array}$ & $\begin{array}{l}43 \\
(35.8 \%)\end{array}$ & $\begin{array}{l}56 \\
(46.6 \%)\end{array}$ & $\begin{array}{l}21 \\
(17.5 \%)\end{array}$ & 120 \\
\hline $\begin{array}{l}\text { lack of technical resources are also part of the challenges of } \\
\text { computer based learning in Unimaid }\end{array}$ & $\begin{array}{l}76 \\
(63.3 \%)\end{array}$ & $\begin{array}{l}27 \\
(22.5 \%)\end{array}$ & $(14.2 \%)$ & 120 \\
\hline $\begin{array}{l}\text { Security policies are one of the challenges of Unimaid computer } \\
\text { based learning }\end{array}$ & $\begin{array}{l}55 \\
(45.8 \%)\end{array}$ & $\begin{array}{l}61 \\
(50.8 \%)\end{array}$ & $04(3.3 \%)$ & 120 \\
\hline $\begin{array}{l}\text { Lack of expert staffs to operate the computer is a challenges of } \\
\text { Unimaid }\end{array}$ & $\begin{array}{l}20 \\
(81.7 \%)\end{array}$ & $11(9.7 \%)$ & 120 \\
\hline
\end{tabular}

Source: Field survey 2019.

The second objectives of the study was to determine the effects of computer based learning on poor academic performance. The respondents were asked to rate their opinion on a Liker scale on the major effects of computer based learning on poor academic performance. On the opinion on how computer based learning affects the performance of students. The result reveals on item I reveals poor management is one of the challenges of computer based learning in Unimaid, $(71.7 \%)$ of the respondent agreed, and $(50.8 \%)$ disagreed while $(3.3 \%)$ of the respondent tick undecided. Item II in table above asked the respondents on inadequate feedback is also a challenges of computer based learning in Unimaid, (53.3\%) of the respondents agreed with the statement, $(34.2 \%)$ disagreed, while $(12.5 \%)$ of the respondents were undecided. While item III were suggested whether lack of technical resources are also part of the challenges of computer based learning in Unimaid, $(40.8 \%)$ agreed and (30.8\%) while (32.5\%) were undecided. Item IV on table 2 above, asked the respondents on whether security policies are one of the challenges of Unimaid computer based learning, $(63.3 \%)$ of the respondents agreed with statement, (37.5\%) disagreed while (7.5\%) were undecided. Finally, item V stated that, lack of expert staffs to operate he computers is also a challenges in Unimaid, (40\%) of the respondents agreed with the statement, $(45.2 \%)$ disagreed while $(10.8 \%)$ of the respondents were undecided.

\section{Summary of Findings}

i. The reveals that, the computer based learning has a great effects on distance learning students' performance

ii. The results shows that, there is challenges of computer based learning on the distance learning students of University of Maiduguri

\section{Conclusion}

At a time when standardized testing is playing an increasingly important role in shaping the learning experiences of students, and instructional practices of teachers, the researchers believe this study provides evidence that students computer based learning has a great effects and challenges on students performance especially in Nigerian Universities.

\section{Recommendation}

i. Consider context before selecting technologies. Contextual factors such as existing technological infrastructure and requirements, program and course characteristics, and the intended audience will help determine which technologies, if any, are most appropriate.

ii. Incentivize students to use technology, either by assigning regular grades or giving extra credit.

iii. Communicate clear guidelines for technology use. Prior to the implementation of technology in a course, students may benefit from an overview the technology, including its navigational features, privacy settings, and security.

iv. University of Maiduguri authority should make sure that all resources and man power of the ICT are in good order before going into computer based learning

\section{References}

Abdul-Rahman. Z. (1994). Factors related to completion of distance education courses in the off-campus degree programme at the university saints of Malaysia. UMI (UMI No. 9425449)

Aiello, N. C., \& Wolfe, L. M. (1980). A meta-analysis of individualized instruction in science. Boston: American Educational Research Association.

Amirault, R. J. (2012). Distance learning in the $21^{\text {st }}$ century university. Quarterly Review of Distance Education, 13(4), 253-265. 
Ani, Okon .E. and Ahiauzu, B. (2008). Towards effective development of electronic information resources in Nigerian University Libraries. Library Management 29 (6/7): 504-514.

Blum, K.D. (1999). Gender differences in asynchrocement learning in higher education: learning styles, participation barriers and communication patterns: Journal of Asychronous

Dung, P.Q., \& Florea, A. M (2012). An approach for detecting learning styles in learning management systems based on learners behaviours. Proceedings of the international Conference on Education and Management innovation (pp. 171-177). Sinpapore: IACSIT

Erben T. et-al (2009). Teaching English language learners through technology. London Rutledge

Ergul. H. (2004). The Relationship between students characteristics and academic achievement in distance education and application to students of anadolu University in Turkish online: Journal of Distance Education 73-88

Garrison, R. \& Anderson, T. (1993). E-Learning in the $21^{\text {st }}$ century: A framework research and practice. London: Routledge Falmer.

Gilbert, S. (1996). Making the Most of a Slow Revolution, Change, 28(2), 10-23.

Johnson, D. R. (2013). Technological change and professional control in the professoriate. Science, Technology \& Human Values, 38(1), 126-149. doi:10.1177/0162243911430236.

Kaware, S. S., \& Sain, S. K. (2015). ICT Application in Education: An Overview. International Journal of Multidisciplinary Approach \& Studies, 2(1), 25-32.

Zielinski, T.J., Swift, M.L. (1997). What ever chemist should know about computers, II Chem. Educator, 2(3), $1430-4171$. 